\title{
EXAMINING TEACHERS' DISPOSITION TOWARDS SUSTAINABLE EDUCATION THROUGH DISCRIMINANT ANALYSIS
}

\begin{abstract}
This research aimed at predicting teachers' disposition to sustainable education from their views regarding the evaluation of curricula and student-centred teaching methods. The attempt was made to develop a convenient discriminant function for placement of teachers in lower, medium and higher levels of disposition to sustainable education. It is a quantitative research conducted on social studies teachers teaching at secondary schools in the central district of Sivas province of Turkey. It was found out that the variables such as perception regarding the evaluation of curricula and attitude towards student-centred teaching methods proved to be statistically significant in distinguishing teachers' attitudes regarding sustainable education by looking at their disposition in this regard. As a conclusion, the discriminant function generated here could provide an accurate classification percentage of $68.7 \%$ above the relative chance criterion.
\end{abstract}

Keywords: sustainable education, disposition towards sustainable education, curricula, student-centred teaching methods.

\section{Introduction}

With each passing day, the interest in education around the world is displaying an upward trend. In particular, international exams play a crucial role in consideration of education on an international scale. Most international exams assessing the quality of formal education underline the need for revising certain aspects of the Turkish education system. Although the 2019 PISA results show progress in all areas compared to the previous years, the overall score of the country continues to remain below the average of OECD member countries (OECD, 2018a). In the TIMSS examination, Turkey fell behind all the other countries on the list (MEB, 2016). Besides these, a standardized examination called "Student Achievement Monitoring Survey" was given by the Ministry of National Education to 112 thousand of $4^{\text {th }}$ grade students selected from all types of schools located in 81 provinces of Turkey. The results revealed that forty percent of the students have poor reading comprehension skills, which means that they cannot understand what they read. Besides, 51 percent of the students were found to be unable to answer the questions requiring reasoning skills in the mathematics test (MEB, 2019). The hardship of finding a suitable employment can be one of the many reasons students drop their education. The European Statistical Office (Eurostat) reported that Turkey is in the first rank for dropping out of school compared to European countries (Eurostat, 2020). It can be argued that the problems associated with the education system in effect itself may be one

\footnotetext{
${ }^{1}$ koybasi.fatma@gmail.com
} 
cause for the poor achievement levels among others. This issue, which is considered in economic aspects may also negatively affect the well-being of the students. What is more, the OECD (2018b) report indicates that employability and unemployment rates among higher education graduates in Turkey are below the average of OECD countries. In another survey probing into students' welfare level alongside academic achievement, Turkey took the last place with a score of 6.12 out of 10 points for "life satisfaction" in the league of 28 OECD countries (OECD, 2015).

The facts above cause uncertainty as to whether education is sustainable or not while hinting at inadequate and substandard components of our education system. In other words, answers are still awaited for questions such as at what extent education is achieving its goals and whether or not individuals can develop behaviours to optimise their life as targeted by formal education. To find the answer to these questions, it is necessary to study multidimensional variables (educational objectives, curricula, learning-teaching situations, education system etc.). When educational organizations are considered from the perspective of the system approach, it can be foreseen that some changes and innovations to be introduced to the process of education can augment the output size. In particular, interventions to certain variables including education and training situations, curriculum, learning and teaching methods, assessment and evaluation, student participation and so on might prove fruitful for the good of the quality of education.

\section{Quality Education}

What we want to reach indirectly with keywords such as "success, effectiveness, development, progress" in education is the quality of education. The multidimensional education and the association of quality with excellence makes it difficult to define quality education.

Although there is no consensus on the definition of quality education, the agreed definition by the international education organization is as follows. It is the success criterion for providing both cognitive development of students and psycho-social development (promoting the values and attitudes of responsible citizenship, providing creative and emotional development) (UNESCO, 2004).

Quality education raises different expectations depending on our perspective on education. There are three models in the literature seeking quality in education (Laurie et al., 2016). With the philosophy of progressivism, our expectation from quality education is the construction of a connected learning model. The connected learning model is education that aims to associate the facts and events we experience in our lives with the concrete and theoretical knowledge we learn at school and consequently, to become a conscious and sensitive individual (LotzSisitka, 2013). As stated by UNICEF (2000), understanding of quality will be redefined according to our knowledge, the environment, and changing contexts. Therefore, since the search for quality in education has a feature that can be handled at the national level, there will be many different examples in the world.

From an economic point of view, quality education is based on the ratio between educational inputs and outputs as well as having the desired properties of measured qualities such as success measured by national and international tests, earnings, costs, etc. (Barrett et al., 2006). 
What is expected from a humanist point of view is the training of individuals who are sensitive to contemporary problems such as human rights and environmental sustainability and can solve them in student-centred, participatory and democratic education environments (Barrett et al., 2006; Kumar \& Sarangapani, 2004).

When blending these three models, it is possible to consider the scope of quality education as follows. It is the individual's development of knowledge, skills, attitudes, and behaviours through education associated with awareness about life (functional), to be a good producer (economic), to understand the society he lives in order to contribute to the society and to have a universal (philosophical) perspective that is sensitive to world problems.

Policies applied to improve and develop education can be realized in the processes related to the purpose, content, method and evaluation of education. Therefore, every aspect of education in terms of improving its quality is significant and not negligible.

\section{Sustainable Education}

The 21st century is becoming the time during which questions such as "What or which education?", "What kind of education?", or "Education for what purpose?" are raised more often than not. Thus, the main objective, content, and method of education are constantly being addressed. In addition to using the power of education to adapt to the changing world or to determine the direction of change, our answer to the question of what kind of world we want will be shaped by the educational philosophy we have adopted. The progressivism and reconstructionism educational philosophies suggest that change is in life and that teaching should be carried out with a constructivist learning approach. The constructivist learning approach which suggests that an internal motivation to gain necessary behaviours and learning by experiencing is required for learning to be realized has been accepted by modern education. In the 21st century, considerable focus has been placed onto curiosity for learning, in-depth understanding, learning by doing, critical thinking, communication skills, and the use of technology as the crucial educational skills (OECD, 2018c). However, reformation is needed on the patterns of excessive consumption, belief and behaviour that threaten the vitality of life, by equipping individuals with ethical, moral, historical and cultural values to strengthen the future (Howard, 2018). It in turn entails an education that both makes sustainable life possible and facilitates adaptation to the conditions of the future.

The type of education which ensures knowledge, skills and attitudes acquired throughout school life to be permanent or even stronger in life outside school, is sustainable education. Sustainable education is the ability of students to put their gains from formal education into practice for life through their multi-dimensional perspectives covering mental, social, and emotional aspects. Sustainable education is the ability to put the behaviours gained in the education and training process into practice in the lives of students with a holistic perspective in social, economic and ecological aspects. Moreover, sustainable education is to provide transformation by providing students with the opportunity to learn by living with a constructivist approach by preparing learning environments such as problem-oriented research, real-life situations, case studies, action researches. When education takes place as life itself, its transformative power can be utilized, thus enabling conscious, sensitive and democratic individuals to shape the future of the world and make it sustainable. Sustainable education, with the reflection of the education given in schools to daily life, is to enter into a collaborative, participative and interactionist partnership provided by social capital in all 
dimensions (economic, sociological, ecological) where each individual can affect the other. Hence, sustainable education not only contributes to society but also provides students' being well-equipped to direct their current and future lives.

Sterling (2001) states that close ties between human being and natural forces will ensure relational and contextual education and learning, namely sustainability. He further emphasises that the sustainable quality of education is the centrepiece of a sustainable life. Education plays an important role to actualise sustainability (Tilbury 2014; Sterling, 2013). Sandell, Ohman and Ostman (2005) argue that everyone has a part to play in establishing sustainable development and such role goes hand in hand with nature, school and democracy. In this respect, providing sustainable education is a multidimensional and interdisciplinary process. Sustainable education typically;

i) creates educational situations in which learners have the curiosity for learning and exhibit in-depth understanding, learning by doing, critical thinking, communication skills, and the use of technology,

ii) aims at bringing up individuals sensitive to and aware of local and global issues,

iii) raises individuals who prefer to live with the consciousness of contribution to the whole in the use of the scarce resources of the universe,

iv) puts in the first place the teaching of knowledge, skills, and attitudes that will make students use learning from formal education in practice throughout their life.

v) adopts values such as right, justice, equality, unity, solidarity, and spirit of sharing for a healthy and merry life (Koybasi Semin, 2020).

It can be said that sustainable education serves two critical purposes, which are to supply students the necessary knowledge and skills for the future and to place emphasis on building a more liveable future in unity and solidarity. At the same time, it encourages students to find settings to nurture their educational achievements by fulfilling educational functions. As a result, sustainable education offers the opportunity for students to grow up with the consciousness of sustainable life.

Sustainable education is based on taking place of change and transformation in a favourably way, building the future robustly, putting ethical values into practice, instilling environmental safety/sensitivity, and creating a positive education culture (Koybasi Semin, 2020). Educational attainments associated with these concerns can be spelt out as follows.

i) Change and transformation: Students are taught social knowledge, life skills, thinking skills, and diverse viewpoints to help them adjust to the changing and transforming conditions of life.

ii) Building the future robustly: As a result of education, students are expected to associate current happenings, events, facts, etc with global issues to transfer potentially useful knowledge and skills to the future with a positive attitude.

iii) Ethical principles: They are educational outcomes that turn students into individuals who embody democratic characteristics, ethical and moral principles, and universal human rights in their lives.

iv) Environmental sensitivity: It is an indispensable feature of sustainable education to leave constructive effects in maintaining the balance of nature as an asset shared by everyone and to raise individuals who are sensitive to nature and environment.

v) Educational culture: The values that will create unity and integrity in education and educational culture formed by collective sharing allow the continuation of the existence of education smoothly. Support can be lent to establish sustainable education by living with a 
sense of collectivism rather than self-interest and setting up an educational culture that puts the spirit of sharing ahead a competitive education environment.

Sustainable education assumes that education will achieve its goals by restructuring educational elements such as curriculum, perspective on education, and pedagogical methods and techniques, etc. It holds that teaching methods should be transformative quality rather than being a tool for merely transferring information, and educational policy should have a participatory quality rather than being imposed. More specifically, it requires a flexible interdisciplinary curriculum which is not too intricate. When it comes to assessment and evaluation, external evaluation should be replaced by self-evaluation, and quantitative measurements should be supplemented with qualitative measurements (Sterling, 2001).

Sterling (2004) contends that sustainable education will be realized through the overall transformation of education, not through the change of individual elements such as pedagogy, curriculum, policy and institutional structures. Also, Yucel (2019) thinks that education systems need reviewing with a holistic approach to curriculum, methodology and evaluation by considering the changing needs of society, the effect of technology on human life, and the characteristics of new generations.

Since evaluating curricula plays an important role in determining the quality of education and reaching the goal of raising qualified people (Stabback, 2016), it was hypothesised that the perception of evaluation of curricula can be an effective tool for delineating tendency to sustainable education. As another variable in this context, attitudes towards student-centred teaching methods and techniques were addressed here. The departing point is the common knowledge that sustainable education can be realized not through traditional teaching methods by transferring items, but learner-centred, transformational, contextual, and interdisciplinary learning methods (Sterling, 2001; Fullan \& Langworthy, 2014b).

In this case, it can be argued that sustainable education can become reality only if curricula are renewed regularly depending on the current and functional needs at the time, pedagogical methods and techniques are put into use in a way to provide meaningful learning, and a process based on self-evaluation is introduced instead of external observers. To this end, the fundamentals of an education process can play an important role in ensuring sustainable education. In this research, the education process was discussed in connection with only two of the variables: "evaluation of curricula" and "attitude towards student-centred teaching methods and techniques". Below are given explanations related to the sub-components of the education process.

\section{Elements of Education Process}

The education process is the process of planned activities targeting to attain goals of formal education. It includes educational situations and managerial activities. It is the collection of operations performed to obtain the desired outputs by putting the system's inputs through a variety of experiences.

Relations among different systems, managerial processes like decision making and planning, management of educational programs, educational situations (teaching activities) included in the program all fall under the operations of the education system (Alic,1991). In other words, factors including education and training activities, pedagogical methods and techniques, 
assessment and evaluation activities, communication and sharing among school stakeholders, etc. are the variables which establish the link between input and output in the education process. Of all these elements, specifically curriculum and pedagogical methods and techniques were studied in this research. Below are given explanations about elements of the educational process handled here.

\section{Curriculum as a Key Complement to Sustainable Education}

The focal point of school curricula is that they contain all educational activities in the school along with a comprehensive process. According to Demirel (2005), a curriculum is the mechanism of learning experiences provided to the learner through planned activities in and outside the school. Over time, the curriculum has evolved into experiences inside and outside the school, an educational guide, or to the understanding of the desirable outcomes, and has been carried away from the list of subjects and lesson contents (Erdem \& Egmir, 2018). In the broadest sense, a curriculum can be defined as the mechanism of learning experiences that students live during the process of schooling (Oliva, 2011). Tyler (1950) introduced several questions during the process of curriculum development as following: i) what educational goals does the school pursue? ii) What educational experiences does the school want to achieve? iii) How can educational practices be put into practice effectively? iv) how can assessment be held on whether the school has achieved the goals? In this way, the curriculum was integrated with dimensions of objectives, content, education and training activities, and assessment and evaluation.

A high-quality education system or curricula with aspirations such as raising qualified manpower and developing social and cultural values resembles a political document representing the social agreement (Stabback, 2016). Curricula take priority in plotting a route for educational leaders as a component that determines and guides the quality of education (Bolat, 2014). A well-structured curriculum is an integral aspect of high-quality education as it would help materialise the curriculum, link it with positive behaviours, and prevent the emergence of wrong or defective situations. Nonetheless, Hunkins and Ornstein (2016) noted that curriculum developers often have trouble combining theory and practice because some activities or practices in a curriculum may not be uniform due the structural, cultural and social peculiarities of individual schools, and there may be lackings or flaws during the implementation. Deng (2011) advocates that a unique curriculum with suitable contents can be put into use in each school. Still, it cannot be denied that making the right decisions that will make the curricula more effective depends on studying these decisions in scientific research and evaluation of the implementations (Erden, 2000). Curricula also represent one of the main factors that determine whether or not education is sustainable because sustainable education has to cover a transformational process to ensure the continuity of educational experiences throughout life (Sterling, 2001). To do this, an evaluation must be carried out on curricula in order to spot factors that prevent fulfilling of the curricular goals or that are ineffectual and to make the necessary amendments accordingly (Usun, 2012).

To provide sustainable education, a shift of paradigm may be necessary for the educational culture and perspective on education. The key to this shift lies in redesigning of curricula. 


\section{Learning and Teaching Processes as a Key Complement to Sustainable Education}

Unlike in the traditional understanding of education, student-centred teaching (SCT) methods are pedagogical processes by which learners construct and interpret knowledge in a customised way through active participation, and by which they learn by living. The constructivist pedagogical approach has been in effect in Turkey since 2005. Since the education process takes place as guided by this approach, the focus is now on the studentcentred learning and teaching process as the learning and teaching pillar.

Student-centred education takes its roots from opposition to the passive and receptive role of learners in the teacher-centred education and acquisition of knowledge through rote learning. Constructivism is characterised with the building of new learning onto the previously learnt topics steered by the student's own experience (Koohang, Riley, \& Smith, 2009).

This type of instruction gives weight to instructional strategies rather than the concepts by enriching and reinforcing pedagogical methods and techniques. The rationale behind this approach is the understanding of developing students' skills and abilities such as critical thinking, solving real-life problems, reflective thinking, collaborative work, self-evaluation, and effective use of technology, which are the indispensable qualities for the 21st century, by using unfamiliar instructional methods (Alista, Ozer \& Kan 2015). These skills are in close congruence with objectives of sustainable education in that intrinsic motivation among objectives of student-centred teaching to actively engage the student in the learning process and making the learning topics more appealing to associate it with real-life (Westwood, 2008) converge with objectives of sustainable education. Of the learner-centred pedagogical methods and techniques; learning through discovery, problem-based learning, collaborative learning, critical and creative thinking, role-playing, debates, projects, product files, fieldwork, and case studies are predominantly used (Attard et al., 2010, Kember, 2008, McCombs, 2013, Tok, 2009).

Although the constructivist education approach is a promising source of support for sustainable education, at what extent constructivism is reflected in education in practice is also as important. It is known that teachers in some of the developing countries still use traditional teaching methods in class despite the adoption of a constructivist education approach at the state policy level (Alista, Ozer, Kan 2015, Schweisfurth, 2011). Even in developed countries, it was found that teachers continue to use teacher centred methods (Deed, 2010; Hoyt ve Perera, 2000; Murphy, 2006), which implies that the constructivist education system is not fully put into implementation in parts of the world. Thus, ensuring sustainable education can be facilitated by incorporating the constructivist knowledge and skills into the education process and developing positive attitudes.

Potential answers to the question "Which elements of education process have a more distinctive variable for sustainable education?" can determine the complement of education process which has a superior effect on education. In this way, a concrete rationale will be laid for restructuring the mentioned elements of the educational process. Therefore, it can function as a mediator in a rearrangement of the variables that bring sustainable education into being. The expected contribution of this research to the education system is to appoint the key point to achieve sustainable education. In other words, this research attempted to determine the mediator variable in leading to educating for democratic and participatory individuals who know how to build a sustainable life as well as ensuring education to be 
functional, realising its goals, and making it up-to-date. The number of researches on the impact of curricula or different learning approaches developed by scientists for the ultimate aim of sustainable education is increasing day by day (Fullan \& Langworty, 2013; Fullan \& Langworty, 2014a; ITL Research, 2011, Adamson, F., \& Darling-Hammond, L. (2012). However, there is a paucity of studies which examine the influence of perception regarding the evaluation of curricula and stance to student-centred pedagogical methods, both of which are among determinants of disposition towards sustainable education. Our research seems promising for the literature on sustainable education from this respect as well. This research aims to develop a discriminant model to distinguish teachers' aptitude to sustainable education.

The research questions are as follow:

In our discriminant model developed to distinguish the level of sustainable education tendency, do the variables of perception of evaluation of curricula and attitudes concerning student-centred teaching methods and techniques play an important role as initially intended? In the discriminant model, what is the accuracy percentage of teachers' scores about the evaluation of curricula and attitude towards student-centred teaching methods and techniques in predicting teachers' disposition towards sustainable education?

\section{Method}

This is a correlational survey carried out with the quantitative method. This model was particularly chosen as it was designed to study the relationship between the sustainability of education and the dimensions of the education process. Correlational surveys are used to identify the degree and direction of the relationship between variables (Karasar, 2011; Frankel, Wallen \& Hyun, 2011).

\section{Population and Sample}

According to the statistical database of Sivas Provincial Directorate of National Education, there were 157 secondary school social studies teachers in the central district of Sivas province at the time of the research. Hence, the research population consisted of 157 teachers. Since the entire of the population was accessible, no sampling method was used. It was tried to reach all of them at once. As a result of sending questionnaires to the target population, 123 copies were returned by the respondents. However, 24 of the questionnaire forms were omitted as they did not comply with the standards of the analysis (12 due to extreme values and 12 due to not being filled out appropriately), leaving 99 sets eligible for the analysis. Table 1 displays demographical information about the participants.

Table 1: Participants' Demographics

\begin{tabular}{lll}
\hline Variable & & $f$ \\
\hline \multirow{2}{*}{ Gender } & Female & 57 \\
\cline { 2 - 3 } & Male & 42 \\
\hline \multirow{2}{*}{ Seniority } & 1 to 8 years & 31 \\
\cline { 2 - 3 } & 8 to 16 years & 33 \\
\cline { 2 - 3 } & Above 16 years & 35 \\
\hline Total & & 99 \\
\hline
\end{tabular}




\section{Data Collection Instruments}

The data for this research were collected with three different data collection tools: sustainable education disposition scale, curriculum evaluation scale, and attitude scale regarding student-centred teaching methods. Each of the scales is described in detail below.

Sustainable education disposition scale: The scale of sustainable education disposition prepared by Koybasi Semin (2020) is a one-dimensional scale consisting of 32 items. Before finalising the scale; the results of Kaiser-Mayer-Olkin (KMO) and Sphericity Barlett test were examined with exploratory factor analysis. The values of $\mathrm{KMO}=0.94$, Bartlett sphericity test=4232,43; $p<0.01$ approved usability of the scale for factor analysis. Scale scores under the sub-scale of sustainability of education could explain $48.68 \%$ of the total variance. Confirmatory factor analysis yielded the values of $x 2 / s d=1279.50 / 461=2.77$ and $R M S E A=0.09$, $\mathrm{RMR}=.05, \mathrm{CFI}=.95$ and NFI $=.97$ were also found. Cronbach's Alpha coefficient was calculated as .96 to indicate the reliability of the sustainable education disposition scale.

Curriculum evaluation scale: The scale developed by Bas (2016) consists of four dimensions with 35 items. The scale was made up of several dimensions as objectives, content, teachinglearning process, and assessment and evaluation. It was completed after exploratory factor analysis, with Kaiser-Mayer-Olkin (KMO) value of 0.940 and Bartlett's sphericity test as $3710.726 \mathrm{p}<.01$. Apart from that, the scale generated the Cronbach Alpha reliability coefficient of 0.92 and Spearman-Brown split-half test correlation of 0.90 .

Attitude scale regarding student-centred teaching methods: It is a 4-dimensional scale with 27 items in total developed by Koc (2014). Exploratory factor analysis yielded significant values, which are KMO coefficient equal to .93 and Bartlett test ( $\mathrm{df}=780, \mathrm{p}<.000$ ). The scale items explained $65.98 \%$ of the total variance. The dimensions of the scale were classified as valuing, resisting, positive effects, and cost belief. Confirmatory factor analysis produced goodness-offit values as RMSEA $=0.082, \mathrm{NFI}=0.95, \mathrm{CFI}=0.96, \mathrm{GFI}=0.80$, and SRMR $=0.056$. Lastly, Cronbach Alpha reliability coefficient of the scale was calculated as 0.93 , and SpearmanBrown two-half test results were found to be 0.64 .

\section{Analysis of Data}

The data collected here were analysed with discriminant analysis. Discriminant analysis is used to predict the groups to which each group of data is attached by calculating the function for distinguishing group members, to identify the strongest independent variables in distinguishing groups, and to decide whether the data are classified correctly (Kalayci, 2014, Verma, 2013). The dependent variable in this research is the disposition to sustainable education, while attitudes towards the evaluation of curricula and student-centred teaching methods and techniques are independent variables. Sustainable education disposition scores were grouped into three by using cluster analysis (k-means clustering). Of the resulting clusters, the mean and standard deviation of the lower disposition group were found to be 2.70 and 0.039 , respectively. Secondly, the medium group provided the mean of 3.69 and the standard deviation of 0.044 . The higher disposition group revealed the mean value of 4.35 and the standard deviation of 0.048 .

For applying discriminant analysis, the first requirement is to fulfil the necessary assumptions (sample size, normal distribution, homogeneity of variance-covariance matrices, extreme 
values, and multiple linear connections). As the first assumption, in order to determine the sample size, the number of participants in the smallest group was set to correspond to at least 4 or 5 folds of the independent variables (Poulsen \& French, 2008).

Secondly, the multivariate normality assumption was tested by looking at whether each variable (predictor variables) showed a univariate normal distribution and whether the combination of these variables was normal (Cokluk, Sekercioglu \& Buyukozturk, 2014). The normality of each variable was evaluated with the Kolmogorov Smirnov test. In addition, skewness and kurtosis coefficients were checked to be sure that they were between -1 and + 1. Kolmogorov-Smirnov test values were .092 for the sustainable education variable, .063 for evaluation of curricula, and .074 for the variable of student-centred teaching methods, all of which were greater than .05 and could meet the normality assumption. Also, the skewness and kurtosis values were seen to range between -1 and +1 for each of the variables. For multivariate normality assumption, checking was done to see whether the correlation between inverse cumulative chi-square values and Mahalanobis distance values was close to 1 . The relationship between Mahalanobis distance values and inverse cumulative chi-square values was .946 , which was almost equal to 1 . Therefore, the assumption of multivariate normality was fulfilled.

As a further criterion, the extreme values were checked for and 12 sets of data with extreme values were removed from the analysis set. Homogeneity of variance-covariance matrices was tested with Box-M statistics. Box-M value was 15.077 and $p=0.33$. Since the significance level of the Box-M test was (p)> .025, the variance-covariance matrix was seen to be homogeneous. Finally, it was tested whether there were multicollinearity problems. In order to discard the risk of multiple linear connections in the case of a strong relationship between the variables, it was sought if; i) the level of relationship between the variables is not greater than .90 (Tabachnik \& Field, 1996); ii) VIF value is $<=10$ and iii) $\mathrm{Cl}$ value is smaller than 30 (Çokluk et al., 2014). In line with the item (i) above, the results experimenting the multiple linear connection were found to comply with the reference values as shown in Table 2.

Table 2: Degrees of relations between the variables 2-Student-centred teaching methods 3-Sustainable education

\begin{tabular}{llll}
\hline $1-$ & Evaluation of curricula & .160 & .760 \\
\hline $2-$ & $\begin{array}{l}\text { Student-centred teaching } \\
\text { methods }\end{array}$ & - & -.077 \\
\hline
\end{tabular}

According to Table 2, there is no correlation value between the variables exceeding the bench of .90. Also; (ii) it was found that the VIF value, which is the multiple variance magnification factor, was $1.026<10$ (iii) and the $\mathrm{Cl}$ value was compliant with the accepted values of 26.42 $<30$. On the whole, the data set were seen to meet the necessary assumptions for discriminant analysis.

Since all of the assumptions were fulfilled, the research data were tested with discriminant analysis. 


\section{Findings}

Among the other dimensions, disposition towards sustainable education consists of three groups. As a result, two discriminant functions were produced for that dimension. The eigenvalues of these functions, which are variance percentages in explaining sustainable education, are given in Table 3.

Table 3: Eigenvalues

\begin{tabular}{cllll}
\hline Function & Eigenvalue & $\begin{array}{l}\text { Variance } \\
\text { percentage }\end{array}$ & $\begin{array}{l}\text { Cumulative } \\
\text { percentage }\end{array}$ & $\begin{array}{l}\text { Canonical } \\
\text { correlation }\end{array}$ \\
\hline 1 & 1.045 & 96.6 & 96.6 & .715 \\
\hline 2 & .036 & 3.4 & 100 & .188 \\
\hline
\end{tabular}

When the eigenvalues implicating the explained variance percentage of the sustainable education disposition were examined, it was seen that function one exhibited the highest power in explaining disposition to sustainable education (eigenvalue $=1.045$; canonical correlation value $=.715$ ) because the function with higher eigenvalue explains a higher variance percentage in statistical terms (Kalaycl, 2014).

Table 4 shows Wilks' Lambda values which are used to understand whether the functions are significant in distinguishing the sustainable education tendency.

Table 4: Wilks' Lambda Results

\begin{tabular}{cllll}
\hline Function & Wilks' Lambda & Chi-square & $\mathrm{df}$ & $\mathrm{p}$ \\
\hline 1 & .472 & 71.755 & 4 & .000 \\
\hline 2 & .965 & 3.419 & 1 & .064 \\
\hline
\end{tabular}

As can be seen in Table 4, function one is significant in distinguishing sustainable education disposition (chi-square $=71.755$ and $p<.01$ ). For this reason, analyses were performed on discriminant statistical data belonging to this function. One of them, data on the equality of Wilks' Lambda Group means are given in Table 5.

Table 5: Wilks' Lambda and F-statistics on Equality of Group Means of Factors

\begin{tabular}{llllll}
\hline Function & Wilks' Lambda & $\mathrm{F}$ & $\mathrm{df}$ & $\mathrm{df2}$ & $\mathrm{p}$ \\
\hline Evaluation of curricula & .447 & 59.334 & 2 & 96 & .000 \\
\hline $\begin{array}{l}\text { Student-centred teaching } \\
\text { methods }\end{array}$ & .916 & 4.401 & 2 & 96 & .015 \\
\hline
\end{tabular}

In Table, significance levels of each independent variable reveal that scores obtained from the curriculum evaluation scale $(f(2,96)=59.334, p<.05)$ and the attitude scale regarding studentcentred teaching methods $(f(2,96)=4.401, p<.05)$ indicate significant differences in all cases. To put simply, both of the variables made a significant contribution to the model.

Then, the standardized canonical function coefficients of the function were checked and displayed in Table 6.

Table 6: Standardized canonical discriminant function coefficients

\begin{tabular}{ll}
\hline & Function 1 \\
\hline Evaluation of curricula & 1.047 \\
\hline Student-centred teaching methods & -.445 \\
\hline
\end{tabular}


In relation with predicting sustainable education disposition, it was seen that perception of evaluation of curricula has the biggest effect level with the coefficients of 1.047 , whereas attitude towards student-centred teaching methods represented the lowest effect level at a negative coefficient level of -.445 . In addition, the structure matrix coefficients showing the relationship between the discriminant function and each independent variable were reviewed and illustrated in Table 7.

Table 7: Structure Matrix Coefficients

\begin{tabular}{ll}
\hline & Function 1 \\
\hline Evaluation of curricula & .906 \\
\hline Student-centred teaching methods & -.115 \\
\hline
\end{tabular}

According to Table 7, there is a relationship at the level of .906 between the function that distinguishes sustainable education disposition and perception of evaluation of curricula. This relationship was found to have the value of .-115 when it comes to attitude towards studentcentred teaching methods. In other words, evaluation of curricula stands out in identifying sustainable education disposition compared to the other variable, attitude regarding studentcentred teaching methods.

The classification statistics obtained from the discriminant analysis are given in Table 8.

Table 8: Results of Classification

\begin{tabular}{lllllllll}
\hline & 1 & & 2 & & 3 & & \multicolumn{2}{c}{ Total } \\
\hline Group & $\mathrm{f}$ & $\%$ & $\mathrm{f}$ & $\%$ & $\mathrm{f}$ & $\%$ & $\mathrm{f}$ & $\%$ \\
\hline 1-low & 10 & 83.3 & 2 & 16.7 & 0 & 0 & 12 & 100 \\
\hline 2-medium & 7 & 15.6 & 25 & 55.6 & 13 & 28.9 & 45 & 100 \\
\hline 3-high & 1 & 2.4 & 8 & 19.0 & 33 & 78.6 & 42 & 100 \\
\hline
\end{tabular}

Overall Percentage of Accurate Classification $=68.7 \%$

Following the analysis, the relative change value was determined to judge the classification accuracy and was calculated by summing the squares of each group's overall percentage value. In total, the relative change value was found to be $(12 / 99)^{2}+(45 / 99)^{2}+(42 / 99)^{2}=$ $0,0144+0,2025+0,1764=0,3933$ for the low, medium and high groups, respectively. As can be understood from the figure above, an accurate classification percentage was equal to 0.68 , considerably above 0.39. It is thus obvious that the discriminant function obtained was capable of making classification far beyond change evaluation. When we look at the accurate prediction rate of the classification, it can be seen that 10 out of 12 units in the low disposition group could be predicted accurately, corresponding to the total accuracy rate of $83.3 \%$. As for the medium group, 25 of the 45 units could be identified correctly, giving the overall accurate classification percentage of $55.6 \%$. Thirdly and lastly, 33 of the 42 units in the high level could be grouped accurately, yielding the accuracy rate of $78.6 \%$. As a whole, the accurate classification percentage of the function that distinguishes sustainable education disposition was found $68.7 \%$.

\section{Conclusion and Discussion}

It was concluded that the two variables, which are the perception of evaluation of curricula and attitude towards student-centred teaching methods and techniques, serve as effective tools to separate groups for their low, medium and high disposition to sustainable education. 
In the literature, no research was available investigating the variables to discriminate sustainable education disposition. Due to this, reference had to be made to studies related to curricula and student-centred teaching approach as influential factors in the education process, the previous findings that are somehow applicable for our context, and the related literature.

It was observed that the function that distinguishes groups with the low, medium and high disposition of sustainable education is negatively correlated to the attitude towards studentcentred teaching methods at a modest level only. It means that as the tendency to sustainable education increases, the attitude towards student-centred teaching methods reaches a bigger negative value. This result seems explicitly against the sustainable education paradigm; however, some research results dealing attitudes or behaviours towards studentcentred teaching methods imply that our result is not unusual.

According to Resnick and Hall (1998), among drivers of a paradigm shift in the education system are the lax occurrences of student-centred education and increased lack of control or aimlessness. It can be inferred that the failure to practise the student-centred teaching approach to fit its purpose as well as the accompanying complexity require remaking of the education system. Previous studies into the circumstances in both developing and developed countries made it clear that the implementation of student-centred teaching is not immune from setbacks at all and that teacher-centred teaching is still widely preferred (Chiu \& Whitebread, 2011; Mtika \& Gates, 2010; Schweisfurth, 2011; Borg, 2011; Lin, Chuang \& Hsu, 2014; De Vries, Van de Grift \& Jansen, 2014; Aliusta, Ozer \& Kan,2015).

Going back to the discriminant power of attitudes regarding student-centred teaching methods in distinguishing sustainable education disposition, its weak force may be due to incomplete and unsatisfactory practising of student-centred teaching methods. Such a practical deficiency might have born a negative relationship between a disposition to sustainable education and the attitude towards student-centred teaching methods. It must be noted that teacher training in Turkey was reframed according to the constructivist education concept as late as after 2018 (YOK, 2018) even though the MoNE introduced the school curricula to the constructivist educational training approach in 2005. This suggests that the teachers who are currently in service were not trained with or for student-centred teaching methods. As Sterling (2001) remarks, sustainable education can be real with the decent implementation of a constructive training method, not through imposition, narration, or expression. Fullan and Langworthy (2013) take 'Citizenship/Culture' and 'Character Education/Connectivity' along with 'Critical Thinking', 'Collaboration', 'Communication' and 'Creativity' as the $21^{\text {st }}$-century skills as a holistic unity founded on the constructivist approach within the framework of "deep learning competences". Sustainable education can also be realised with deep learning competencies.

The other variable studied here, perception of evaluation of curricula, exhibited a very strong relation with the disposition to sustainable education in terms of distinguishing groups with low, medium and high levels of tendency. This is to confirm that formal curricula are one of the key factors for sustainable education. We believe that the previous research about the content, implementation and implications of curricula are important for the evaluation of curricula. 
A blend of formal curricula with attainments such as a sense of societal contribution for a peaceful world in harmony with life itself, environmental sensitivity, adoption of universal human rights, and creative and critical thinking is thought to be indispensable for bringing sustainable education into life. That type of education can make a difference if a healthy and natural system is to be rebuilt, rather than in the context of adaptation to an existing system. So far, school curricula have been shaped around absolute concern about performance at examinations and strict implementation with no decision-making initiative of teachers even though the need exists for a model of a curriculum which is preparatory for life, allows individuals to become themselves and go united with nature and real-life problems, teaches through living, and which attaches importance to social activities and growing up as favourable individuals besides academic success; consequently, how and why curricula are adopted has faded into the background (Bumen, 2019). However, OECD reports that increased professional autonomy of teachers is associated with higher levels of student achievement when decisions regarding curriculum and evaluation are in question (TEDMEM, 2015). UNESCO Global Education Monitoring Report indicates that Turkey is one of the countries where teachers have the smallest share in deciding on the course content, even their autonomy in this regard has declined steadily since 2006 up to now (UNESCO-GEM, 2017). Yildiz (2014) thinks that today's manifest teacher typology is a "technician teacher who prepares students for examinations". It is seen that the end of dreams has come and that a pedagogical paradigm based on technical-scientific education instead of holistic education of the individual, has been accepted as fate. In contrast to what is in place, school curricula are supposed to have a functional value in teaching life skills and be able to integrate theory and practice (Friere, 2017). Hunkins and Ornstein (2016) demonstrate that curriculum developers usually face difficulty in blending theory and practice, the existing curricula are dominated by pure theoretical knowledge, and decent implementation of curricula is not taking place. Failures in the curriculum may impede upbringing of strong future generations because policies make visible the characteristics of the prospective manpower in that country in the formal curricula and thus aim to attain their set goals (Oliva, 2001). In the case of unscientific, inconsistent and unsustainable educational policies (Aydin, 2015), it may be unlikely to make education sustainable.

\section{Recommendations}

In light of the results of this research, the following steps regarding school curricula and student-centred teaching methods can be suggested for sustainability education.

The motto of sustainable education is "The school should be the very life". This philosophy needs to be concretised in school curricula so that students can acquire a positive attitude of learning and living besides academic success. To this end, it is recommended that the formal curricula should be revised or reconfigured by curriculum development experts working for the Ministry of National Education (MoNE).

Flexible programs should be offered which would turn teachers into active and autonomous actors so that they can understand and fully implement the given curriculum.

Teacher training should be aligned with the new education system of MoNE for efficient implementation of student-centred teaching methods for the eventual aim of realising sustainable education. More study time should be allocated to practical parts of teacher training courses structured in 2018. 
In institutions training teachers, the faculty members must keep up with the latest knowledge and practices concerning pedagogical methods and techniques.

Again, the faculty members should teach their classes by using different teaching methods and techniques (demonstration, case study, problem-solving, debate, teaching methods, station, storytelling, drama techniques, etc).

Hands-on in-service training should be organised for teachers by the Ministry of National Education about student-centred education methods.

In this research, the effects of school curricula and student-centred teaching methods were searched for segregating groups with low, medium and high tendency of sustainable education. It is advised that colleague researchers should devise practical studies to evaluate curricula and discover the effect of sustainable education.

Lastly, a probe can be conducted into the effects of curricula revolving around studentcentred teaching methods on the level of sustainable education tendency.

\section{References}

Adamson, F., \& Darling-Hammond, L. (2012). Policy pathways for 21st century skills. Stanford center for opportunity policy in education. Retrieved from http://atc215.org/wpcontent/uploads/2012/08/ATC21Slaunch-LDH-policyii.pdf .

Alic, M. (1991). Egitim bilimlerinde cagdas gelismeler. Eskisehir: Anadolu Universitesi Acikogretim Fakultesi Yayinlari.

Aliusta, G. O., Ozer, B. ve Kan, A. (2015). Ogrenci-merkezli ogretim stratejilerinin Kuzey Kibris'taki okullarda uygulanmasi. Egitim ve Bilim, 40(181), 77-91.

Attard, A., E. Di Lorio, K. Geven, \& R. Santa. (2010). Student-centred Learning - Toolkit for Students, Staff and Higher Education Institutions. Brussels: European Students Union. http://www.esib.org/index.php/Publications .

Aydin, A. (2015). Egitim politikasi. Ankara: A Pegem yayincilik.

Barrett, A. M., Chawla-Duggan, R., Lowe, J., Nikel, J., \& Ukpo, E. (2006). The concept of quality in education: A review of the 'international' literature on the concept of quality in education (EdQual Working Paper No. 3). Bristol, the UK: EdQual RPC.

Bas, G. (2016). Egitim programlarini degerlendirme olcegi: Gecerlik ve guvenirlik calismasi. Turkish Journal of Educational Studies, 3(1), 53-80.

Bolat, Y. (2014). Ogrenci gozuyle sinifin ortuk programi. Adiyaman Universitesi Sosyal Bilimler Enstitusu Dergisi, 2014(18), 510-536.

Borg, S. (2011). The impact of in-service teacher education on language teachers' beliefs. ScienceDirect, 39(3), 370-380. doi:10.1016/j.system.2011.07.009.

Bumen, N. T. (2019). Turkiye'de merkeziyetcilige karsi ozerklik kiskacinda egitim programlari: Sorunlar ve oneriler. Kastamonu Egitim Dergisi, 27(1), 175-185.

Chiu, M. S. ve Whitebread, D. (2011). Taiwanese teachers' implementation of a new "constructivist mathematics curriculum": How cognitive and affective issues are addressed. International Journal of Educational Development, 31(2), 196-206.

Cokluk, O., Sekercioglu, G., \& Buyukozturk, S. (2014). Sosyal bilimler icin cok degiskenli istatistik: SPSS ve LISREL uygulamalari, Ankara: Pegem Akademi. 
De Vries, S., Van de Grift, W. J. C. M. \& Jansen, E. P. W. A. (2014). How teachers' beliefs about learning and teaching relate to their continuing professional development. Teachers and Teaching: Theory and Practice, 20(3), 338-357. doi:10.1080/13540602.2013.848521.

Deed, C. G. (2010). Where do I begin? A case study of student self-regulation. The International Journal of Learning, 17(1), 443-453.

Demirel, O. (2005). Kuramdan uygulamaya egitimde program gelistirme, Ankara: Pegem A Yayincilik.

Deng, Z. (2011). Revisiting curriculum potential. Curriculum Inquiry, 41(5), 538-559.

Erdem, C., \& Egmir, E. (2018). Ogretmen adaylarinin egitim programi okuryazarligi duzeyleri. Afyon Kocatepe Universitesi Sosyal Bilimler Dergisi, 20(2), 123-138.

Erden, M. (2000). Egitimde program degerlendirme (3. baski). Ankara: Ani Yayincilik.

Eurostat (2020). Early_leavers_from_education_and_training, 2014-2018. Retrieved from https://ec.europa.eu/eurostat/statistics-

explained/index.php?title=File:Early_leavers_from_education_and_training,_2014_and 2019_(\%25_of_population_aged_18-24).png.

Frankel, J. R., Wallen, N. E., \& Hyun, H. H. (2011). How to design and evaluate research in education. (8. edition). New York: McGraw-Hill.

Freire, P. (2017). Ozgurlugun Pedagojisi (Cev. D. Hattatoglu ve E. Ozbek) 15. Baski, Istanbul: Yordam Yayinlari.

Fullan, M. \& Langworthy, M. (2014a). A Rich Seam: How New Pedagogies Find Deep Learning.

Retrieved from http://www.michaelfullan.ca/wpcontent/uploads/2014/01/3897.Rich_Seam web.pdf

Fullan, M. \& Langworthy, M. (2014b). Towards a New End: New Pedagogies for Deep Learning. Usa: Collaborative Impact Seattle, Retrieved from http://www.newpedagogies.nl/images/towards_a_new_end.pdf.

Fullan, M., \& Langworthy, M (2013). Towards a New End: New Pédagogies for Deep Learning, Seattle: Collaborative Impact.

Howard, P. (2018). Twenty-First Century Learning as a Radical Re-Thinking of Education in

Hoyt, D. ve Perera, S. (2000). Teaching approach, instructional objectives and learning. Manhattan, Kans: IDEA Centre, Kansas State University.

Hunkins F. P. \& Ornstein A. C. (2016). Curriculum: Foundations, principles, and issues. England: Pearson Education.

ITL Research. (2011). Innovative Teaching and Learning Research: 2011 Findings and Implications. Retrieved from http://www.itlresearch.com/research-a-reports/2011-itlresearch-findings.

Kalayci, S. (2014). Spss uygulamali cok degiskenli istatistik teknikleri. Ankara: Asil Yayin Dagitim.

Karagoz, Y. (2017). SPSS ve AMOS uygulamalı nitel-nicel bilimsel arastırma yontemleri ve yayin etigi, Ankara: Nobel Yayincilik.

Karasar, N. (2011). Bilimsel arastırma yontemi. Ankara:Nobel.

Katz, D. \& Kahn, R. L. (1977). Orgutlerin Toplumsal Psikolojisi, (Cev.: Can, H. ve Bayar, Y.) Ankara: Turkiye ve Ortadogu Amme Dairesi Enstitu Kitaplari.

Kember, D. (2009). Promoting student-centred forms of learning across an entire university." Higher Education 58 (1): 1-13. doi:10.1007/s10734-008-9177-6.

Koc, C. (2014). Ogrenci merkezli ogretim yontem ve tekniklerini kullanmaya yonelik tutum olcegi: Gecerlik ve guvenirlik calismasi. Electronic Journal of Social Sciences, 13(49), 150170.

Koohang, A., Riley, L. \& Smith, T. (2009). E-Learning and Constructivism: From Theory to Application. Presented at the Informing Science \& Information Technology Education Conference, Macon, Georgia. 
Koybasi Semin, F. (2020). Developing Sustainable Education Disposition Scale and Teacher Views regarding the Disposition. Journal of Education and Future, 17,65-81.

Kumar, K., \& Sarangapani, P. M. (2004). History of the quality debate. Contemporary Education Dialogue, 2(1), 30-52.

Laurie, R., Nonoyama-Tarumi, Y., Mckeown, R., \& Hopkins, C. (2016). Contributions of education for sustainable development (ESD) to quality education: A synthesis of research. Journal of Education for Sustainable Development, 10(2), 226-242.

Lin, M. H., Chuang, T. F. \& Hsu, H. P. (2014). The relationship among teaching beliefs, studentcentred teaching concept and the instructional innovation. Journal of Service Science and Management, 7, 201-210.

Lotz-Sisitka, H. (2013). Conceptions of quality and 'learning as connection': Teaching for relevance. Southern African Journal of Environmental Education, 29, 25-38.

McCombs, B. L. (2013). The learner-centred model: Implications for research approaches. In Interdisciplinary Handbook of the Person-Centred Approach (pp. 335-352). Springer, New York, NY.

MEB (2016). TIMSS 2015 ulusal matematik ve fen bilimleri on raporu 4.ve 8. siniflar. Retrieved from

http://kmarasodm.meb.gov.tr/meb_iys_dosyalar/2019_02/08101550_TIMSS_2015_Ulus al_Rapor.pdf.

MEB (2019). 2019 yili 4. sinif-seviyesi-turkce-matematik-fen-bilimleri-ogrenci-basari-izlemearastirmasi. Retrieved from https://www.meb.gov.tr/2019-4sinif-seviyesi-turkcematematik-fen-bilimleri-ogrenci-basari-izleme-arastirmasi-tmf-oba-sonuc-raporuaciklandi/haber/19362/tr.

Mtika, P. \& Gates, P. (2010). Developing learner-centred education among secondary trainee teachers in Malawi: The dilemma of appropriation and application. International Journal of Educational Development, 30, 396-404.

Murphy, B. (2006). Child-centred practice in Irish infant classrooms: A case of imaginary play? International Journal of Early Childhood, 38(1), 112-124.

Neuman, W.L. (2009). Social research methods: Quantitative and qualitative methods (7. Ed.). Boston, MA, EE. UU: Allyn \& Bacon.

Nitto, A. J., \& Brookhart, S. M. (2016). Ogrencilerin egitsel degerlendirmesi. (Ceviri Ed.: Bicak, B. Bahar, M. ve Ozel, S.). Ankara: Nobel Yayincilik.

OECD (2015). Students' well-being report. Retrieved from https://www.oecd.org/education/pisa-2015-results-volume-iii-9789264273856-en.htm .

OECD (2018a). OECDiLibrary. Retrieved from https://www.oecdilibrary.org/education/education-at-a-glance-2019 f8d7880d-en.

OECD (2018b). Turkey - Country note - Education at a glance: OECD indicators. Retrieved from https://stats.oecd.org/Index.aspx?DatasetCode=STLABOUR.

OECD (2018c). OECD, 2018. The future of education and skills Education 2030. https://www.oecd.org/education/2030/E2030\%20Position\%20Paper\%20(05.04.2018).pdf

Oliva, P. F. (2001). Developing the curriculum. (15th ed.), Boston: Scott, Foresman and Company.

Poulsen, J., \& French, A. (2008). Discriminant function analysis. Retrieved from http://userwww.sfsu.edu/efc/classes/biol710/discrim/discrim.pdf

Resnick, L. B., \& Hall, M. W. (1998). Learning organizations for sustainable education reform. Daedalus, 127 (4), 89-118.

Sandell, K., Ohman, J., \& Ostman, L. (2005). Education for Sustainable Development: Nature, School and Democracy Lund, Sweden: Studentlitteratur. 
Schweisfurth, M. (2011). Learner-centred education in developing country contexts: From solution to problem? International Journal of Educational Development, 31(5), 425-432.

Srivastava M. S. \& Carteri, E. M. (1983). An intıoduction to applied multivariate statistics, New York: Elsevier Science Publishing Co., Inc.

Stabback, P. (2016). What makes a quality curriculum?, Current and critical issues in curriculum and learning, Retrieved 02.02.2018 from http://unesdoc. unesco.org/ images/0024/002439/243975e.pdf.

Sterling S (2013). The sustainable university: challenge and response. In: S. Parkin, Sterling S., Maxey L. \& Luna, H. (eds) The sustainable university: progress and prospects.(pp 1750). London: Routledge

Sterling, S (2001) Sustainable Education - Re-Visioning Learning and Change, Dartington: Green Books,

Sterling, S. (2004). Higher education, sustainability, and the role of systemic learning. In Higher education and the challenge of sustainability (pp. 49-70). Dordrecht: Springer.

Stiggins, R., Arter, J., \& Chappuis, J. (2002). Assessment for learning. Education Week, 21(26), 30.

Tabachnick, B. G. \& Field, L. S. (1996). Using multivariate statistics. New York: Hcorper

TEDMEM (2015). Ogretmen ozerkligi ve okul ozerkligi uzerine. Retrieved from https://tedmem.org/mem-notlari/ogretmen-ozerkligi-ve-okul-ozerkligi-uzerine the Service of Life. Education Sciences, 8(4), 189.

Tilbury, D. (2014). Education for sustainability in higher education. Report commissioned by UNESCO ESD secretariat to inform the 3rd Global DESD report and global action programme.

Tok, S. (2009). Ogrenme-ogretme strateji ve modelleri. A. Doganay (Yay. haz.), Ogretim ilke ve yontemleri icinde (s. 130-157). Ankara: Pegem Akademi Yayincilik.

Tyler, R. W. (1950). Basic principles of curriculum and instruction. Chicago, Illinois: The University of Chicago Press.

UNESCO-GEM, (2017). Global education monitoring report 2017-2018: Accountability in education. France, United Nations Educational, Scientific and Cultural Organization Publishing. Retrieved from http://unesdoc.unesco.org/images/0025/002595/259593e.pdf.

UNICEF (2000). Defining Quality in Education. A paper presented by UNICEF at the meeting of The International Working Group on Education Florence. Italy, June.

Usun, S. (2012). Egitimde program degerlendirme: Surecler, yaklasimlar ve modeller. Ankara: Ani Yayincilik.

Verma, J. P. (2013). Data Analysis in Management with SPSS Software, India: Springer.

Westwood, P. S. (2008). What Teachers Eeed to Know about Teaching Methods. Camberwell, Vic.:Acer Press.

Yildiz, A. (2014). Idealist ogretmenden sinava hazirlayici teknisyene: Ogretmenligin donusumu. Istanbul: Kalkedon yayinlari.

YOK (2018). Ogretmen yetistirme lisans programlari. Retrieved from https://www.yok.gov.tr/Documents/Kurumsal/egitim_ogretim_dairesi/Yeni-OgretmenYetistirme-Lisans-Programlari/AA_Sunus_\%200nsoz_Uygulama_Yonergesi.pdf

Yucel, E. (2019). A life dedicated to education. Washington DC: Mentora Publishing. 


\section{Biographical notes:}

Fatma Köybaşı Şemin is a doctor lecturer in the Department Of Educational Administration at Sivas Cumhuriyet University in Turkey. Her current research interests are sustainable education, quality in education, education administration and teacher training. 